\title{
PENGGUNAAN HADIS-HADIS PADA SKRIPSI MAHASISWA IAIN PONTIANAK
}

\author{
Wajidi Sayadi \\ IAIN Pontianak, Indonesia \\ Email:wajidi.zayadi@gmail.com
}

Diterima Tangal: 10 Mei 2019

Selesai Tanggal 26 Mei 2019

\section{ABSTRACT}

This research was conducted to find out how the writing and quality of the Hadith of the Prophet Muhammad in the thesis of students of the Department of Islamic Education, Tarbiyah Faculty and Teacher Training of IAIN Pontianak, in academic year 2013/2014. The research methods used includes; First, do takhrij al-hadith; Second, do I'tibar al-hadith; Third, examine the narrators' personalities and methods of transmission by using, among others, the knowledge of al-jarh wa at-ta'dil. Fourth, conclude the results of the study. There are 100 theses studied, only 25 theses (25\%) have hadiths in them, and 75 theses (75\%) that do not include hadiths. There are two types of hadith writing in student thesis: First, hadith are written in Arabic text and their translations. Second, only the translation of the hadith was written. In writing the hadith of the Arabic text there are several errors. There is even a hadith text that is different from the translation. This happens, because most of the thesis is about improving the reading of the Qur'an in a particular school. The quality of the hadiths in student theses is 66 Sahih hadiths, 7 Hasan hadiths, 8 Daif Hadiths, 2 very daithic hadiths, 1 false hadith, 1 mauquf hadith, and 1 not known quality of hadith. Students' understanding of the hadith writing and the quality of the hadith is still lacking. Thesis supervisors and examiners are negligent in seeing the traditions of the hadith used by students.

[Penelitian ini dilakukan untuk mengetahui bagaimana penulisan dan kualitas hadis-hadis Nabi Muhammad SAW dalam skripsi mahasiswa Jurusan Pendidikan Agama Islam Fakultas Tarbiyah dan Ilmu Keguruan IAIN Pontianak tahun akademik 2013/2014. Adapun metode penelitian yang digunakan antara lain; Pertama, melakukan takhrij al-hadits; Kedua, melakukan I'tibar al-hadits; Ketiga, meneliti pribadi para periwayat dan metode periwayatannya dengan menggunakan antara lain ilmu al-jarh wa at-ta'dil. Keempat, menyimpulkan hasil penelitian. Ada 100 skripsi yang diteliti, hanya 25 skripsi (25\%) yang ada hadis di dalamnya, dan 75 skripsi $(75 \%)$ yang tidak mencantumkan hadis. Ada dua macam cara penulisan hadis dalam skripsi mahasiswa: Pertama, hadis ditulis dalam teks Arab dan terjemahannya. Kedua, hanya terjemahan hadisnya yang ditulis. Dalam penulisan hadis teks Arabnya terdapat beberapa kekeliruan. Bahkan ada yang teks hadisnya berbeda dengan terjemahannya. Hal ini terjadi, karena kebanyakan skripsi mengenai upaya peningkatan membaca al-Qur'an di suatu sekolah tertentu. Adapun kualitas hadis-hadis dalam skripsi mahasiswa, adalah 66 hadis Sahih, 7 hadis Hasan, 8 hadis Daif, 2 hadis sangat daif, 1 hadis palsu, 1 hadis mauquf, dan 1 hadis yang belum diketahui kualitasnya. Pemahaman mahasiswa dalam hal penulisan hadis dan kualitas hadis masih sangat kurang. Para pembimbing dan penguji skripsi lalai dalam melihat keshahihan hadis yang digunakan oleh mahasiswa].

Kata Kunci: Hadis, Skripsi, Mahasiswa, Sahih, Da'if, dan Palsu. 


\section{PENDAHULUAN}

Hadis Nabi Muhammad SAW. adalah sumber ajaran Islam yang kedua setelah al-Qur'an. Sumber ajaran Islam yang dimaksud meliputi masalah akidah, ibadah, hukum halal dan haram, pendidikan, dakwah, peradaban, dan lainnya. Hanya saja, masalahnya tidak semua hadis dapat dijadikan standar dan sumber sebagaimana yang dimaksud di atas, sebab kualitas hadis bermacammacam tingkatannya. Ada yang sahih, daif, dan bahkan ada yang palsu. Dalam realitas kehidupan umat Islam, khususnya dalam proses pembelajaran dan penyampaian serta penerapan hadis-hadis Nabi SAW terkadang justru hadis-hadis yang populer dan seringkali digunakan dan disampaikan, disinyalir adalah hadis-hadis daif bahkan hadis palsu. Berdasarkan pengalaman di tengah-tengah masyarakat, seringkali mendengar langsung dari mimbar masjid pada waktu khutbah jumat, khatibnya menyampaikan bahwa Rasulullah SAW.bersabda:

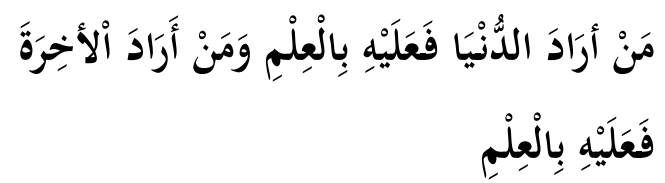

"Barangsiapa menghendaki dunia, maka hendaklah berilmu. Barangsiapa menghendaki akhirat, maka hendaklah berilmu".

Apa yang diklaim sebagai hadis tersebut ternyata hanyalah pernyataan
Imam Syafìi (204 H/820 M), bukan hadis Nabi SAW ${ }^{1}$. Pengalaman penulis tahun 2008 meneliti hadis-hadis populer yang diceramahkan para muballig di Kota Pontianak, membuktikan bahwa 21 hadis yang sering diceramahkan para muballig; ada 12 hadis yang palsu, enam hadis munkar, satu hadis matruk, dan satu hadis sangat daif, serta satu hadis daif "ringan" yang sebenarnya adalah ucapan sahabat, bukan ucapan Nabi SAW. Kesimpulannya, dari 21 hadis yang sering diceramahkan itu, tak ada satu pun yang sahih, namun sudah terlanjur populer di masyarakat.

Pada tahun 2012 penulis meneliti hadis-hadis yang terdapat dalam buku pelajaran al-Qur'an Hadis Madrasah Ibtidaiyah dan Tsanawiyah sesuai Kurikulum 2008 berdasarkan Permenag. RI No. 2 Tahun 2008 ditemukan bahwa 18 hadis yang dipelajari di Madrasah Ibtidaiyah, hanya 11 hadis yang kualitasnya sahih.Satu hadis hasan, dua daif, satu palsu, dan empat hadis sangat daif. Adapun di Madrasah Tsanawiyah ada 21 hadis yang dipelajari, ternyata hanya 12 hadis yang kualitasnya sahih, tiga hadis palsu, empat hadis sangat daif, satu hadis daif, dan satu lagi bukan hadis ucapan Nabi SAW melainkan ucapan sahabat, itu pun kualitasnya daif. Demikian juga pengalaman sebagai dosen, baik sebagai

1 Ali Mustafa Yaqub, Kritik Hadis (Jakarta: Pustaka Firdaus, 2003), hlm. 71-72. 
pembimbing maupun penguji pernah menemukan beberapa hadis dalam skripsi yang tidak selayaknya dimuat sesuai perspektif ilmu hadis.Berdasarkan pengalaman dan pemikiran tersebut, di atas, apakah pengalaman tersebut juga terjadi dalam penulisan dan penggunaan hadis-hadis dalam Skripsi mahasiswa IAIN Pontianak?

Oleh karena itu, penulis meneliti mengenai penggunaan hadis-hadis Nabi Muhammad SAW.dalam skripsi mahasiswa Jurusan Pendidikan Agama Islam Fakultas Tarbiyah dan Ilmu Keguruan IAIN Pontianak tahun akademik 2013/2014. Penelitian ini diarahkan pada skripsi mahasiswa tahun akademik 2013/2014 karena inilah angkatan pertama IAIN Pontianak sejak beralih status dari Sekolah Tinggi Agama Islam Negeri (STAIN) tahun 2014.

Ada beberapa tujuan yang diharapkan dalam penelitian ini adalah mengetahui kualitas hadis-hadis yang ditulis para mahasiswa Jurusan Pendidikan Agama Islam Fakultas Tarbiyah dan Ilmu Keguruan IAIN Pontianak dalam skripsi.Kualitas hadis-hadis dalam skripsi ini menggambarkan pengetahuan dan kemampuan mahasiswa menerapkan ilmu hadis dan hadis yang telah mereka peroleh dan pelajari selama perkualiahan. Idealnya, apa yang diperoleh selama kuliah hadis dan ilmu hadis hasilnya akan dituangkan dalam karya ilmiah skripsi sebagai landasan dan pijakan suatu masalah yang dibahas. Demikian juga perhatian para pembimbing dan penguji terhadap penulisan hadis-hadis tersebut dalam skripsi.

Penggunaan hadis yang dimaksud dalam penelitian ini ada dua sisi; pertama, sisi wurud atau sumber asal hadis tersebut.Dilihat dari sisi inilah, kemudian muncul istilah kualitas sanad hadis, apakah sahih, daif, atau palsu.Kedua, sisi dilalahnya, yakni petunjuk dari makna yang terkandung dalam hadis tersebut.Bagaimana menempatkan hadis sesuai pada konten dan konteksnya.Oleh karena itu, masalah yang dirumuskan dalam penelitian ini adalah analisis terhadap hadis-hadis Nabi SAW.dalam skripsi mahasiswa Jurusan Pendidikan Agama Islam Fakultas Tarbiyah dan Ilmu Keguruan IAIN Pontianakn yang sudah diujikan dan diwisuda tahun akademik 2013/2014.,Alasannya bahwa mereka sudah mengikuti mata kuliah 'Ulumul Hadits dan Hadis Tarbawi, lebih khusus lagi mereka adalah mahasiswa calon guru atau pendidik. Keberadaan mereka sebagai guru atau pendidik adalah sangat urgen karena akan menjadi narasumber informasi dan inspirasi bagi anak didiknya. Skripsi mahasiswa tahun akademik 2013/2014 
yang dipilih merupakan angkatan pertama diwisuda sejak beralih status dari STAIN menjadi IAIN Pontianak. Oleh karena itu, masalah dalam penelitian ini akan dibatasi pada dua hal, yaitu: 1) Bagaimana penulisan hadis-hadis dalam skripsi mahasiswa IAIN Pontianak?; 2) Bagaimana kualitas hadis-hadis dalam skripsi mahasiswa tersebut?; dan, 3) Bagaimana peran pembimbing dan penguji skripsi mahasiswa tersebut?

Dalam rangka mengetahui kualitas hadis-hadis yang digunakan dalam skripsi mahasiswa Jurusan Pendidikan Agama Islam Fakultas Tarbiyah dan Ilmu Keguruan IAIN Pontianak akan dianalisis dengan menggunakan ilmu kritik hadis. Muhammad Mustafa A`zhamî, mendefinisikan bahwa ilmu kritik hadis sebagai ilmu yang membahas dan menetapkan adanya ke-tsiqah-an atau kecacatan pada diri pribadi periwayat sehingga dengan demikian dapat dipisahkan antara hadis sahih dan hadis daif.Apa yang didefinisikan A'zhami tersebut, dilengkapi oleh Muhammad Thahir al-Jawâbî̀ , "Ilmu kritik hadis

2 Muhammad Mushthafâ A`zhamî, 1402 H/1982 M, Manhaj an-Naqd `ind al-Muhadditsîn Nasy'atuhî wa Târikhuhû (Riyâdh: Syirkah athThibâ'ah al-`Arabiyah as-Su’ûdiyah al-Mahdûdah, Cet. II., 1402 H/1982 M), hlm. 5.

${ }^{3}$ Muhammad Thâhir al-Jawâbî, Juhûd alMuhadditsîn fî Naqd Matn al-Hadîts an-Nabawî̀ asy-Syarîf (Tunis: Muassasât "Abd al-Karîm ibn 'Abdullâh, t.th.), hlm. 94. adalah ilmu yang berusaha menetapkan kecacatan atau keadilan pada periwayat dengan menggunakan term-term (lafallafal) tertentu yang didasari oleh sejumlah argumentasi yang jelas, dan menilai teksteks hadis itu apakah sahih atau daif, serta berusaha menghilangkan kemusykilan yang mungkin ada padanya dan mendudukkan secara proporsional hal-hal yang tampak kontradiktif dalam hadis itu dengan menggunakan kaedah secara cermat. Ilmu kritik hadis diklasifikasi oleh Shalahuddin bin Ahmad al-Idlibi (1403 H/1983 M: 31), dalam dua macam, yaitu naqdal-khârijî yakni kritik sanad, 2) naqdad-dâkhilî yakni kritik matan.Sanad adalah jalan yang menyampaikan pada matan hadis, yaitu berupa rangkaian para periwayat yang menyampaikan hadis dari Rasulullah SAW. Dinamakan sanad (sandaran) karena mereka (para periwayat) itu menyandarkan hadis itu kepada sumbernya yakni Nabi SAW. Sedangkan matan adalah materi hadis setelah sanad berakhir ${ }^{4}$. Dengan demikian, kritik sanad adalah suatu penelitian dan penilaian terhadap para periwayat yang terdapat dalam rangkaian sanad dengan menggunakan term-term tertentu, seperti lafal at-tajrîh dan lafal at-ta`dîl. Kalau periwayat tersebut terbukti al-jarh $\underline{h}$ maka ia dinilai daif dan hadisnya pun dinilai daif.

${ }^{4}$ Ahmad 'Umar Hâsyim, Qawầid Ushûl al-ㅍadîts (Beirut: Dâr al-Fikr, t.th.), hlm. 21-22. 
Sebaliknya, kalau terbukti bahwa iatsiqah berarti hadisnya dinilai sahih. Tujuan kritik sanad ini adalah untuk mengetahui sejauhmana kualitas hadis itu. Kalau hadis itu memenuhi kriteria kesahihan sanad berarti hadis itu sahih dari segi sanad.Sebaliknya, kalau tidak memenuhi kriteria tersebut, maka hadis tersebut adalah daif. Bahkan kalau tidak ada sanadnya berarti bukan hadis.Kalau tetap disebut hadis, maka itulah disebut sebagai hadis palsu.

Adapun kritik matan adalah penelitian terhadap isi hadis itu sendiri, berupa ucapan, perbuatan, dan taqrir Nabi SAW.Kritik matan atau materi teks hadis, landasan dan acuan yang digunakan adalah pada kriteria kesahihan hadis yang telah disebutkan di atas. Dua di antaranya berkaitan dengan matan, yaitu bersih dari syadz (rancu) dan `illat (cacat). Pengertian rancu dalam ilmu hadis adalah maknanya bertentangan dengan dalil atau hadis lainya yang lebih kuat dan unggul.Sedangkan mengandung 'illat (cacat), maksudnya hadis itu terdapat kekeliruan dalamnpenulisan hadisnya, baik dalam hal penulisan nama periwayat maupun dalam penulisan matannya. Dalam kritik matan ini menggunakan metode muqâran (perbandingan) dengan hadis-hadis lainnya sehingga dapat diketahui susunan lafal matan hadis yang sebenarnya lebih unggul dapat dipertanggungjawabkan validitasnya berasal dari Rasulullah SAW. Dengan metode muqâran ini akan diketahui kemungkinan adanya ziyâdah (tambahan), idrâj (sisipan), dan lain-lain yang dapat berpengaruh pada kedudukan matan hadis itu sendiri.

$$
\text { Ibn al-Jauzî }(597 \quad \mathrm{H} / 1210 \quad \mathrm{M})^{5} \text {, }
$$
menyusun kriteria kritik matan yang sangat singkat, namun cukup padat. Menurutnya, setiap hadis yang menyalahi akal sehat atau bertentangan dengan ketentuan pokok agama, maka ketahuilah bahwa hadis itu adalah maudhi' (palsu), maka jangan dijadikan i'tibar (pertimbangan)". AlKhathîb al-Bagdadî (463 H/1072 M) (1972: 433), merumuskan bahwa matan hadis dapat diterima selama ia memenuhi kriteria: 1) Tidak bertentangan dengan akal yang sehat. 2) Tidak bertentangan dengan hukum al-Qur'an yang muhkam, maksudnya ketentuan hukum yang sudah tetap. 3) Tidak bertentangan dengan sunnah mutawatir. 4) Tidak bertentangan dengan amalan sunnah yang telah disepakati oleh ulama salaf. 5) Tidak bertentangan dengan dalil yang qath $i$ (yang sudah pasti). 6) Tidak bertentangan dengan hadis ahad yang kesahihannya sudah pasti. Selain rumusan Ibn al-Jauzî

5 Jamâl ad-Dîn ibn `Ali ibn Muhammad ibn al-Jauzî, Kitâb al-Maudhû̀ât, (Beirût: Dâr alFikr, 1983), hlm. I: 106. 
dan al-Baghdadî di atas, al-Idlibî (1983 M: 238) menyimpulkan bahwa ada empat landasan utama yang patut dijadikan acuan dalam ilmu kritik matan hadis, yaitu 1) Tidak bertentangan dengan petunjuk alQur'an. 2) Tidak bertentangan dengan hadis dan sejarah kehidupan Nabi. 3) Tidak bertentangan dengan akal yang sehat, indera, dan sejarah, dan 4) Susunan pernyataannya menunjukkan ciri-ciri sabda kenabian.

Skripsi adalah karya tulis ilmiah mahasiswa berdasarkan hasil penelitian lapangan dan atau studi kepustakaan yang disusun sesuai dengan bidang studinya sebagai tugas akhir dalam studi formalnya.Tema dan masalah yang ditulis oleh mahasiswa dalam skripsi biasanya mengaitkan dengan jurusan dan kompetensinya.Salah satu mata kuliah yang terkait dengan hadis-hadis mengenai pendidikan adalah Hadis Tarbawi dan sebelumnya sudah mengikuti mata kuliah 'Ulumul Hadits.

Secara umum, terdapat beberapa hasil penelitian mengenai analisis terhadap hadis-hadis yang terdapat dalam suatu karya ilmiah yang boleh dikatakan ada hubungannya dengan penelitian yang dilakukan ini, antara lain:

1. Kualitas Hadis-Hadis dalam Tafsir AlAzhar: Studi Kritik Matan Hadis dalam Surah Yasin oleh Siti Masyitoh Skripsi UIN Syarif Hidayatullah Jakarta 2010.
Hadis sebagai bagian dari uraian tafsir yang terdapat dalam surah Yasin yang diteliti hanya delapan hadis. Hasilnya menunjukkan bahwa semuanya sahih karena maknanya tidak ada yang bertentangan al-Qur'an, hadis yang lebih unggul, dan fakta sejarah.

2. Takhrij Hadis-hadis Kitab Tafsir alMishbah (Studi Kritik Sanad dan Matan Hadis pada Surah al-Rahman) oleh Asep Badru Takim Skripsi UIN Syarif Hidayatullah Jakarta 2010. Hadis sebagai bagian dari uraian tafsir yang terdapat dalam surah al-Rahman yang diteliti hanya tiga hadis. Hasil takhrij yang dilakukan menunjukkan satu daif, satu hasan gharib, dan satu lagi sahih.

3. Hadis-hadis yang Dipelajari di Madrasah Ibtidaiyah dan Tsanawiyah Sesuai Kurikulum 2008 Berdasarkan Permenag. RI No. 2 Tahun 2008 oleh Wajidi Sayadi. Hasilnya menunjukkan bahwa 18 hadis yang dipelajari di Madrasah Ibtidaiyah, hanya 11 hadis yang kualitasnya sahih. Satu hadis hasan, dua daif, satu palsu, dan empat hadis sangat daif. Adapun di Madrasah Tsanawiyah ada 21 hadis yang dipelajari, ternyata hanya 12 hadis yang kualitasnya sahih, tiga hadis palsu, empat hadis sangat daif, satu hadis daif, dan satu lagi bukan ucapan Nabi SAW. melainkan ucapan sahabat, itu pun kualitasnya daif. 
Penelitian tersebut di atas menggunakan metode ilmu kritik hadis dengan obyek pada sanad dan matan hadis yang terdapat dalam kitab tafsir dan buku pelajaran yang diteliti.Adapun secara khusus penelitian hadis-hadis yang terdapat dalam skripsi mahasiswa IAIN Pontianak, belum pernah dilakukan.

\section{METODE}

Tempat penelitian ini adalah di Fakultas Tarbiyah dan Ilmu Keguruan IAIN Pontianak di Jalan Letjen Soeprapto No. 19 Pontianak. Dalam proses penelitian ini untuk mendapatkan data yang diperlukan mengenai Jurusan Pendidikan Agama Islam meliputi para pimpinan yang membuat kebijakan tentang penetapan para pembahas draft skripsi, pembimbing dan penguji serta pengesahan skripsi mahasiswa. Demikian juga penetapan para dosen yang mengampu dan mengajarkan mata kuliah ilmu hadis dan hadis tarbawi.Jumlah mahasiswa dan skripsi yang diselesaikanya dan diwisuda pada tahun akademik 2013/2014 sebagai angkatan pertama selama beralih status dari STAIN menjadi IAIN Pontianak. Proses pencarian dan penghimpunan data tersebut dilakukan di Fakultas Tarbiyah dan Ilmu Keguruan khususnya Jurusan Pendidikan Agama Islam. Para mahasiswa setelah menyelesaikan skripsi dan wisuda, terdapat beberapa kewajibannya, antara lain; menyerahkan salinan foto copi skripsi ke bagian Akademik dan kemahasiswaan Fakultas Tarbiyah dan Ilmu keguruan dan Perpustakaan IAIN Pontianak. Oleh karena itu, tempat penelitian di ruang Fakultas Tarbiyah dan Ilmu Keguruan dan di ruang Perpustakaan IAIN Pontianak.

Penelitian ini menggunakan metode analisis deskriptif dengan cara mengumpulkan data, menyusun, atau mengklasifikasi, menganalisis, dan menginterpretasikannya (Natsir, 1999). Hadis-hadis yang terdapat dalam skripsi tersebut diteliti dan dianalisis dengan menggunakan metode kritik hadis. Adapun yang dimaksud metode kritik hadis sebagaimana dirumuskan al-Jawâbî (t.th.: 94), yaitu ilmu yang berusaha menetapkan kecacatan atau keadilan pada periwayat dengan menggunakan lafal-lafal tertentu yang didasari oleh sejumlah argumentasi yang jelas, dan menilai teks-teks hadis itu apakah sahih atau daif, serta berusaha menghilangkan kemusykilan yang mungkin ada padanya dan mendudukkan secara proporsional hal-hal yang tampak kontradiktif dalam hadis itu dengan menggunakan kaedah secara cermat. Sedangkan al-Idlibi (1403 H/1983 M: 31), merumuskan dua langkah metode kritik hadis; 1) naqdal-khârijî yakni kritik sanad, 2) naqdad-dâkhilî yakni kritik matan. 
Penerapan metode ini dengan beberapa langkah, yaitu:

1. Melakukan Takhrij al-Hadits, yaitu menunjukkan letak asal hadis dalam sumbernya yang asli di berbagai kitab yang diriwayatkan lengkap dengan sanadnya disertai dengan penjelasan derajatnya sesuai dengan kebutuhan ${ }^{6}$.

2. Melakukan I'tibar al-hadits, yaitu menyertakan sanad-sanad yang lain untuk suatu hadis tertentu yang hadis itu pada bagian sanadnya tampak hanya terdapat seorang periwayat saja; dan dengan menyertakan sanad-sanad tersebut akan diketahui apakah ada periwayat lain atau tidak untuk bagian sanad dari sanad hadis yang dimaksud ${ }^{7}$.

3. Meneliti pribadi para periwayat dan metode periwayatannya dengan menggunakan antara lain ilmu al-jarh wa at-Ta'dil, yaitu ilmu yang membahas tentang penilaian negative terhadap orang yang meriwayatkan hadis sehingga mengakibatkan riwayatnya perlu diteliti, dipertimbangkan, atau ditolak, lalu orang yang meriwayatkan hadis yang sudah dinilai adil riwayatnya diterima karena orang itu sudah memiliki sifat-

${ }^{6}$ Mahmûd Ath-Thahhân, Ushûl at-Takhrîj wa Dirâsât al-Asânîd, (Riyâdh: Maktabah alMa ârif, Cet. III, 1412 H/1991 M, hlm. 10.

7 M. Syuhudi Ismail, 1992, Metodologi Penelitian Hadis Nabi, (Jakarta: Bulan Bintang, Cet. I., 1992), hlm. 51. sifat sebagai orang yang harus diterima riwayatnya ${ }^{8}$.

4. Menyimpulkan hasil penelitian hadis.

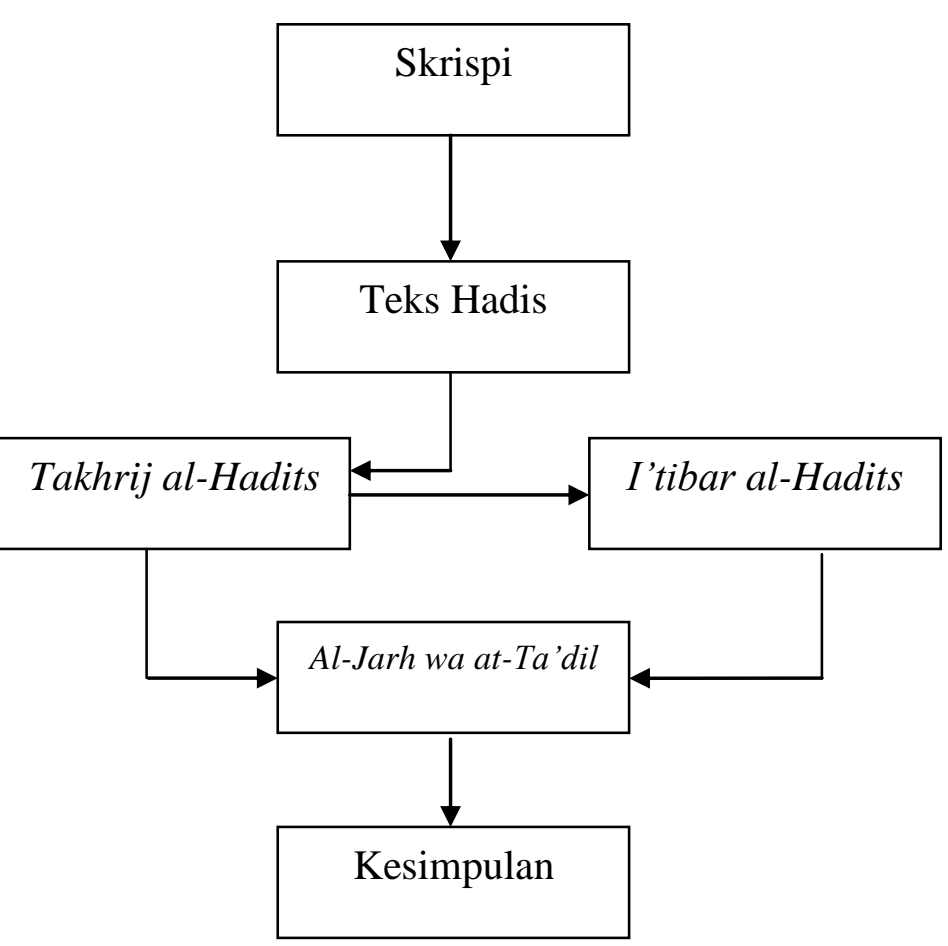

Data merupakan sekumpulan informasi yang diperoleh dari sumber data.Sumber data dalam penelitian adalah subyek dari mana data itu diperoleh.Dalam penelitian kualitatif, sumber data dapat berupa informan (orang yang memberi informasi), peristiwa atau aktifitas, tempat atau lokasi, dan dokumen atau arsip.Sumber data dalam penelitian ini ada yang primer (utama) dan ada juga yang sekunder sebagai pelengkap.Adapun sumber data primer dalam penelitian ini

8 M. Abdurrahman dan Elan Sumarna, Metode Kritik Hadis, (Bandung: Rosda, Cet. I., 2011) hlm. 59. 
adalah skripsi mahasiswa Jurusan Pendidikan Agama Islam Fakultas Tarbiyah dan Ilmu Keguruan IAIN Pontianak tahun akademik 2013-/2014. Skripsi para mahasiswa yang memuat hadis-hadis inilah yang akan diteliti dan dianalisis dengan menggunakan metode ilmu kritik hadis. Sedang sumber sekunder yang dapat melengkapi data yang diperlukan adalah para pimpinan dan pejabat yang terkait dapat memberikan informasi dan data yang diperlukan di lingkungan Fakultas Tarbiyah dan Ilmu Keguruan khususnya Jurusan Pendidikan Agama Islam.Mereka ini yang lebih paham mengenai data tentang jumlah mahasiswa dan skripsi mereka.

Adapun teknik pengumpulan data dalam penelitian ini adalah menggunakan dokumentasi.Dokumen merupakan bahan tertulis atau benda yang berkaitan dengan suatu peristiwa atau aktivitas tertentu. Dokumen bisa merupakan rekaman atau dokumen tertulis seperti arsip data base surat-surat rekaman, skripsi, tesis, disertasi, buku, gambar benda-benda peninggalan yang berkaitan dengan suatu peristiwa, termasuk jadwal kegiatan aktivitas mahasiswa, jumlah mahasiswa, jumlah jumlah dosen dan pegawai, kitabkitab atau buku-buku acuan dan referensi, daftar sarana, arsip, dan sejenisnya yang terkait dalam proses pembelajaran.
Dokumen yang digunakan dalam penelitian ini adalah skripsi mahasiswa Jurusan Pendidikan Agama Islam Fakultas Tarbiyah dan Ilmu Keguruan IAIN Pontianak tahun akademik 2013/2014.

\section{PEMBAHASAN}

\section{Penulisan Hadis-Hadis dalam Skripsi} Mahasiswa

Jumlah skripsi mahasiswa Pendidikan Agama Islam yang telah diwisuda tahun akademik 2013/2014 adalah 210 mahasiswa. Jumlah yang begitu banyak dipilih hanya 100 yang menjadi obyek penelitian ini.Setelah melakukan penelitian terhadap 100 skripsi mahasiswa ditemukan hanya 25 skripsi yang ada menuliskan hadis.Ada 75 skripsi (75\%) tidak ada menuliskan hadis dalam skripsinya.Sedangkan jumlah hadis yang terdapat dalam 25 skripsi tersebut adalah 86 hadis.Adapun rinciannya adalah sebagai berikut:

Ada 9 skripsi yang di dalamnya hanya satu hadis saja.Ada 6 skripsi yang tertulis di dalamnya 2 hadis.Ada 4 skripsi yang memuat hanya 3 hadis.Dua skripsi yang terdapat di dalamnya hanya 4 hadis.Ada menulis 5 hadis, 7 hadis, 10 hadis, dan 19 hadis dalam masing-masing satu skripsi.Dengan demikian, jumlah hadis yang terbanyak dalam satu skripsi adalah 19 hadis, dan yang paling sedikit 
adalah satu hadis dalam satu skripsi.Cara penulisan hadis dalam skripsi tersebut beragam. Secara garis besarnya ada dua macam cara: Pertama, hadis ditulis dalam teks Arab dan terjemahannya. Kedua, hadis ditulis, hanya terjemahannya saja.

Adapun hadis yang ditulis dalam teks Arab dan diiringi terjemahannya, misalnya:

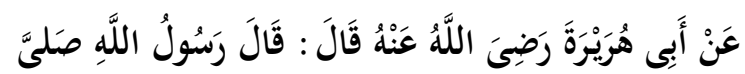

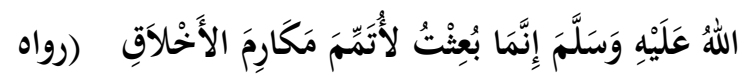

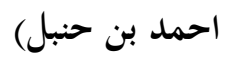

Dari Abu Hurairah Radhiyallahu 'anhu, ia berkata: "Rasulullah SAW. bersabda: "Sesungguhnya Aku diutus untuk menyempurnakan akhlak. (HR. Ahmad bin Hambal).

Teks hadis yang ditulis dalam bahasa Arab sekaligus terjemahannya sebanyak 57 hadis.

Adapun yang ditulis hanya terjemahan hadisnya saja. Misalnya:

Dari 'Aisyah ra, ia berkata: Rasulullah SAW. bersabda: "Orang yang mahir membaca al-Qur'an, maka nanti akan berkumpul bersama-sama para malaikat yang mulia lagi taat. Sedangkan orang yang kesulitan dan berat jika membaca alQur'an, maka ia mendapat dua pahala".(HR. Bukhari dan Muslim).

Hadis yang ditulis dalam bentuk terjemahannya saja seperti ini sebanyak 19 hadis. Penulisan hadis dalam teks Arabnya juga beragam. Secara rinciannya, adalah sebagai berikut:
1. Ada hadis yang ditulis teks Arabnya, tapi lain terjemahannya. Contoh dan pembuktiannya dikemukakan pada bagian analisis.

2. Ada hadis yang ditulis teks Arabnya tanpa harakat,.

3. Ada hadis yang ditulis lengkap nama sumber riwayatnya, matan hadis, dan periwayatnya, yakni mukharrijul hadis.

4. Ada hadis yang ditulis hanya sumber riwayatnya, matannya, dan tidak ditulis mukharrijul hadis.

5. Ada yang ditulis matan hadis dan mukharrijul hadisnya, tanpa sumber riwayatnya,

6. Ada yang ditulis hanya teks matan hadis saja, tanpa sumber riwayat dan mukharrijul hadisnya.

Ada teks hadis ditulis dengan harakatnya, dan ada juga hadis tanpa harakat.Dalam satu skripsi ada yang menulis satu hadis, ada dua hadis, bahkan ada sampai 19 hadis, inilah yang terbanyak.Misalnya hadis

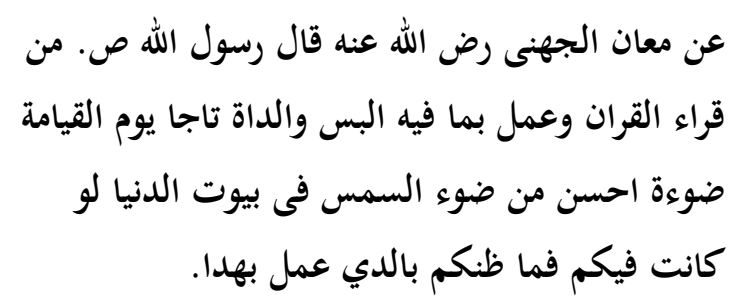

Artinya: Dari Sayyidina ibnu Mas'ud Radhiyallahu 'anhu, Baginda Rasulullah Shallallahu 'alaihi wasallam bersabda, "barangsiapa membaca satu huruf dari kitab Allah Subhanahu wata'ala, maka baginya satu hasanah (kebaikan). Satu 
hasanah itu, pahalanya sepuluh kali lipat. Aku tidak mengatakan bahwa alif laam miim satu huruf, tetapi alif satu huruf, lam satu huruf, dan mim satu huruf. (HR. Tirmidzi dan Darami).

Terjemahan yang ditulis dalam skripsi ini keliru.Antara teks hadis dan terjemahannya berbeda. Oleh karena itu, terjemahan ini akan dijadikan satu hadis tersendiri dalam analisis. Selain itu, penulisan teks hadis tersebut juga banyak yang keliru. Berdasarkan hasil penelusuran peneliti, teks hadis yang sebenarnya adalah:

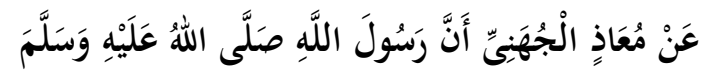

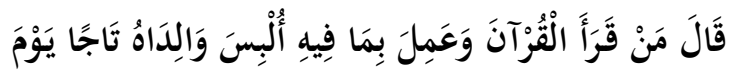

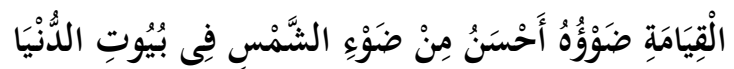

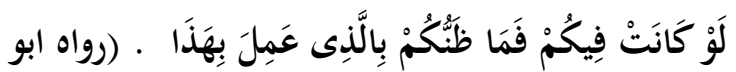

داود)

Termasuk hadis

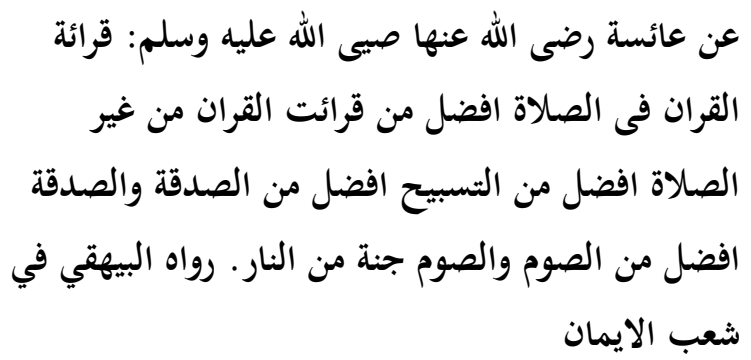

Teks hadis yang sebenarnya sebagaimana dalam kitab Sya'b al-Iman (V/256) karya Baihaqi adalah:

عن عائشة رضي الله عنها أن النبي صلى الله عليه وسلم قال قراءة القرآن في الصلاة أفضل من قراءة القرآن في غير الصلاة وقراءة القرآن في غير الصلاة أفضل من سن سترات التكبير والتسبيح والتسبيح أفضل من الصدقة والصدقة
أفضل من الصوم والصوم جنة من النار (رواه البيهقي في

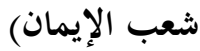

Termasuk juga hadis

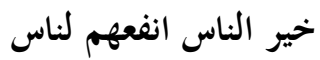

Tulisan لناس seharusnya للناس.

\section{Kualitas Hadis-hadis dalam Skripsi Mahasiswa}

Kualitas hadis sangat ditentukan oleh sanad dan para periwayatnya serta makna yang terkandung dalam hadis itu sendiri. Sebagaimana disebutkan pada paparan data di atas bahwa ada 86 hadis yang ditemukan dalam 25 skripsi. Penelitian ini menunjukkan bahwa terdapat 66 hadis sahih, 7 hadis hasan, 8 hadis daif, 2 hadis sangat daif, 1 hadis palsu, 1 ucapan sahabat Nabi SAW. atau hadis mauquf, dan satu hadis yang belum diketahui. Ada beberapa hadis yang terdapat dalam beberapa skripsi hingga 10 kali terulang, misalnya:

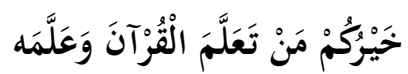

Hadis ini terulang hingga 10 kali terdapat dalam 10 skripsi.Hadis ini mengenai keutamaan belajar dan mengajarkan al-Qur'an.Hadis ini banyak dikutip dalam 10 skripsi, disebabkan karena memang judul skripsi banyak mengenai upaya peningkatan bacaan alQur'an pada tempat-tempat tertentu.

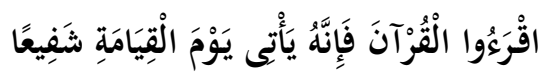


Hadis ini terulang empat kali dalam empat skripsi.

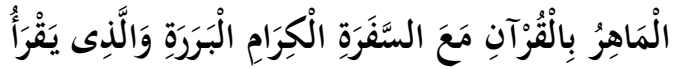

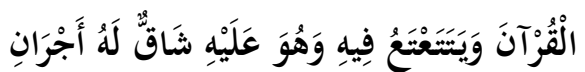$$
\text { Hadis ini terulang empat kali }
$$

dalam empat skripsi.

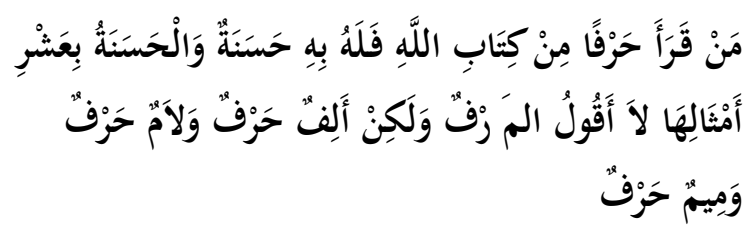

Hadis ini terulang empat kali dalam empat skripsi.

$$
\text { إنَّمَا بُعِنْتُ لأُتَمَّمَ مَكَارِمَ الأَخْلاَقِق }
$$

Hadis ini terulang tiga kali dalam tiga skripsi.

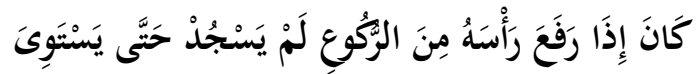

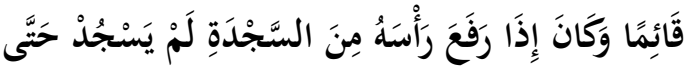

$$
\begin{aligned}
& \text { يَسْتَوِيَ جَالِسنًا }
\end{aligned}
$$

Hadis ini terulang tiga kali dalam tiga skripsi.Hadis ini termasuk hadis ahkam mengenai praktek Nabi Muhammad SAW.shalat. Hadis ini sebetulnya cukup panjang.Lalu dibagi tiga, setiap bagian dikutip sesuai dengan konteksnya.

Adapun hadis hasan sebanyak 7 hadis, yaitu:

Abdullah bin Mas'ud menceritakan bahwa Nabi SAW bersabda, "Barang siapa yang membaca satu huruf dari kitab Allah, ia akan mendapatkan kebaikan, satu kebaikan akan mendapat pahala sepuluh kali lipat. Saya tidak mengatakan Alif Lam Mim satu huruf, melainkan Alif satu huruf, Lam satu huruf, dan Mim satu huruf. (HR. Tirmidzi).

Hadis ini dimuat dua kali dalam dua skripsi, kualitasnya hasan sahih gharib sesuai pernyataan Tirmidzi yang meriwayatkan hadis ini.

Hadis ke-20,

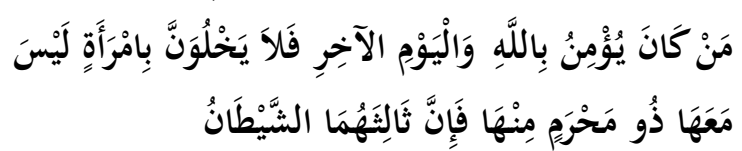

Hadis ini diriwayatkan imam Ahmad bersumber dari Jabir bin Abdullah. Menurut Syu'aib al-Arnauth bahwa hadis ini sanadnya daif, yaitu Ibnu Lahi'ah hapalannya buruk.Hadis yang daif disebabkan karena hapalan buruk periwayatnya dikategorikan hadis daif "ringan". Hadis daif "ringan" boleh diangkat dan naik derajatnya, apabila ada hadis lain yang menguatkan. Oleh karena ada hadis lainnya yang memperkuatnya, maka hadis ini kualitasnya berubah dan naik derajatnya menjadi hasan li ghairihi. Adapun hadis yang memperkuatnya adalah hadis riwayat Tirmidzi dan Hakim bersumber dari Abdullah bin Umar.

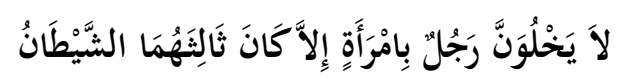

Menurut Tirmidzi hadis ini hasan sahih, dan Hakim menilainya sebagai sahih.

Hadis ke 25, "Mencari ilmu adalah diwajibkan bagi setiap muslim." (HR. Ibnu Majah).

طَلَبُ

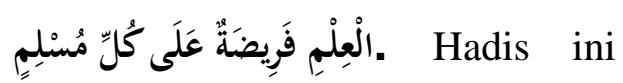
diriwayatkan Ibnu Majah bersumber Anas bin Malik. Hadis mengenai kewajiban belajar juga diriwayatkan Abu Ya'la dan 
Thabarani dari Ibnu Umar, Ibnu Mas'ud, Ali bin Abi Thalib, Abu Said, dan lainnya. Ada beberapa kitab hadis, misalnya azZawâid menyebutkan bahwa hadis tersebut daif. Salah satu sebab ke-daif-annya ialah dalam sanadnya terdapat seorang periwayat bernama Hafash bin Sulaiman adalah daif. Imam an-Nawawi (676 H) pernah ditanya mengenai hadis tersebut.Jawabnya, hadis tersebut daif sanadnya walaupun maknanya sahih.Syekh Jamaluddin al-Mizzi menilai bahwa hadis tersebut diriwayatkan melalui banyak jalur sanad mencapai 50 jalur sehingga mencapai derajat hadis hasan.Maksudnya hadis hasan li ghairihi, yaitu hadis daif yang berubah menjadi hadis hasan karena adanya dukungan dari hadis-hadis lainnya.

Hadis ke- 52,

تهادوا تحابوا

"Jadilah kalian saling memberi hadiah, maka kalian akan saling mencintai”

Hadis ini ditulis hanya matannya saja, tanpa sanad dan periwayat.Setelah ditelusuri, ditemukan bahwa hadis ini diriwayatkan Baihaqi bersumber dari Abu Hurairah. Menurut Husain Salim Asad, bahwa hadis ini kualitasnya daif. Bukhari juga meriwayatkan hadis ini dalam kitabnya al-Adab al-Mufrad, bukan dalam Shahih al-Bukhari.Abu Ya'la juga meriwayatkannya. Ash-Shan'ani dalam kitabnya Subul as-Salam menjelaskan bahwa hadis tersebut kualitasnya hasan, sebab ada hadis lain yang menguatkannya. Penilaian Husain Salim Asad bahwa hadis tersebut daif adalah benar, hanya saja karena ada hadis lainnya yang memperkuat, maka kualitasnya berubah dan naik derajatnya menjadi hasan $l i$ ghairihi.

Hadis ke- 53,

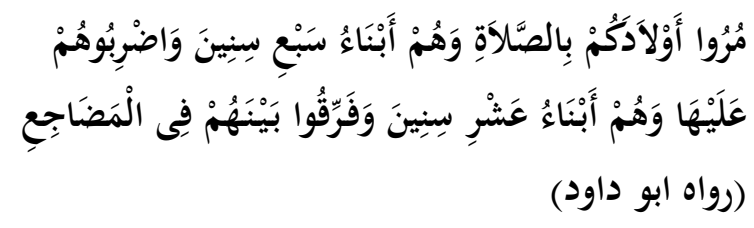

Hadis ini bersumber dari Abdullah bin 'Amr bin 'Ash. Beberapa periwayat meriwayatkan hadis ini antara lain; Abu Daud, Ahmad, Ibnu Abi Syaibah, Abu Nu'aim, Hakim, dan Baihaqi. Syekh Syu'aib al-Arnauth menilainya hadis ini hasan.Imam an-Nawawi dalam kitab Riyadh ash-Shalihin menilainya sebagai hadis hasan.

Hadis ke- 63, Hadis riwayat Ahmad dari Abu Hurairah:

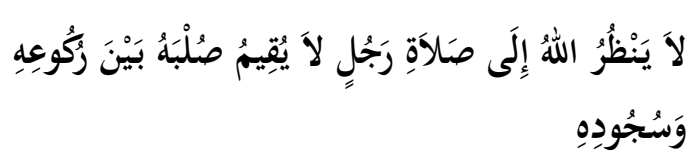

Syuaib al-Arnauth menilai hadis ini kualitasnya hasan.Al-Albani menilainya sebagai sahih li ghairihi. 
Hadis ke- 71, HR. Tirmidzi dari Abdullah bin Umar

أَنَّ النَّبَّ صلى الله عليه وسلم كَانَ إذذَا جَلَسَ فِى الصَّلاَةِ

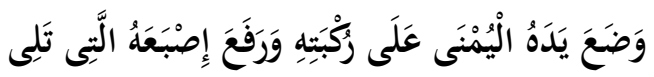

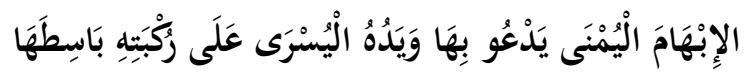

عَلَيْدِ

Kata Tirmidzi, hadis ini kualitasnya hasan.

Hadis ke- 81,

$$
\text { خير الناس انفعهم لناس }
$$

Hadis ini sumbernyadari Jabir. Periwayatnya adalah Baihaqi dan Thabarani.

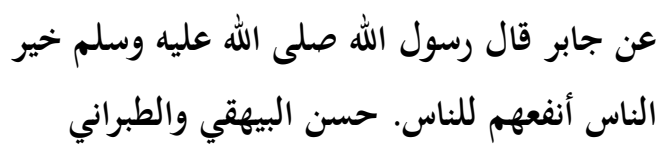

Baihaqi dan Thabarani menilai bahwa hadis ini adalah hasan.

Adapun hadis daif sebanyak delapan, yaitu:

$$
\begin{aligned}
& \text { عن معان الجهنى رض الله عنه قال رسول الله ص. من } \\
& \text { قراء القران وعمل بما فيه البس والداة تاجا يوم القيامة } \\
& \text { ضوءة احسن من ضوء السمس فى بيوت الدنيا لو } \\
& \text { كانت فيكم فما ظنكم بالدي عمل بهدا. }
\end{aligned}
$$

Terjemahan yang ditulis dalam skripsi ini keliru.Antara teks hadis dan terjemahannya berbeda sebagaimana dijelaskan di atas pada analisis penulisannya.Hadis ini diriwayatkan Abu Daud dan Ahmad bersumber dari Mu'adz al-Juhani. Menurut Husain Asad, bahwa hadis ini kualitasnya daif. Al-Albani juga menilainya daif.

Termasuk hadis ini,

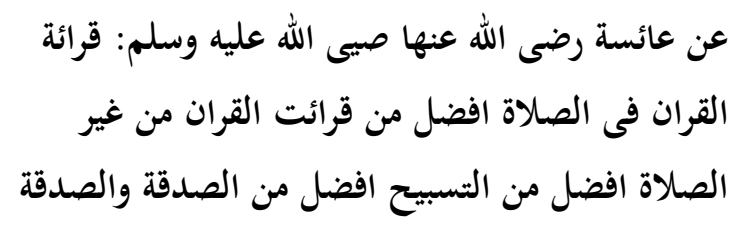

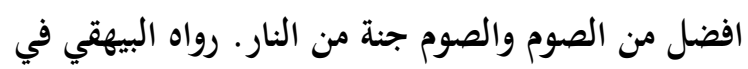

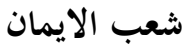

Selain Baihaqi, Daruquthni juga meriwayatkan hadis tersebut dalam kitab al-Afrad. Al-Albani dalam kitab Misykah al-Mashabih (I/490), menilai bahwa hadis tersebut daif.

Hadis ke- 42. Bacaan ketika thawaf:

سبحان الله والحمد الله ولا اله الا الله والله

اكبر لاحول ولا قوة الا بالله (رواه ابن ماجه)

Hadis tersebut diriwayatkan Ibnu Majah bersumber dari Abu Hurairah. Adapun hadis selengkapnya:

مَنْ طَافَ بِالْبَيْتِ سَبْعًا وَلاَ يَتَكَلَّمُ إلالَّ بِسُبْحَانَ اللَّهِ

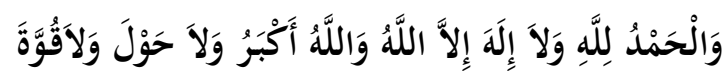

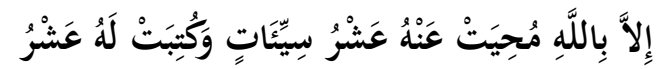

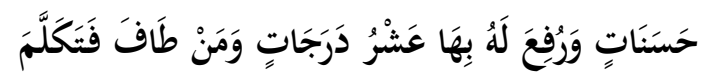

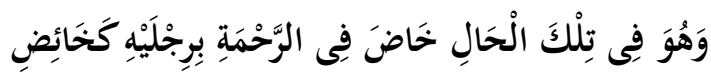
الْمَاِِ برِجْلَيْهِ

Barangsiapa thawaf di Baitullah 7 kali dan tidak berbicara kecuali “، بسُبْحَانَ اللَّهِ

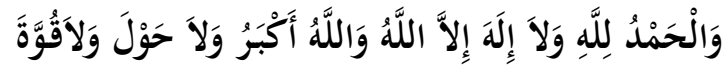
”ِٕالَّ بِاللَّهِ kebaikannya baginya akan dicatat, dan 10 derajatnya akan diangkat. Barangsiapa bertawaf lalu berbicara padahal ia sedang 
dalam keadaan tawaf berarti ia bercebur ke dalam rahmat hanya kedua kakinya (tidak semua badannya) seperti menceburkan kedua kakinya ke dalam air. (HR. Ibnu Majah dari Abu Hurairah).

Menurut as-Sindi hadis ini tidak Mahfuzh.Hadis yang tidak mahfuzh disebut hadis syadz (rancu), yakni bagian dari hadis daif.Al-Albani menilai hadis ini daif.

Hadis ke- 47

Barangsiapa merendahkan diri kepada saudaranya sesama muslim, maka Allah akan meninggikan derajatnya. Dan barangsiapa sombong terhadap saudaranya sesama muslim, maka Allah akan merendahkan derajatnya. (HR. Thabrani).

Setelah ditelusuri ditemukan bahwa teks hadis dari terjemahan tersebut, ialah

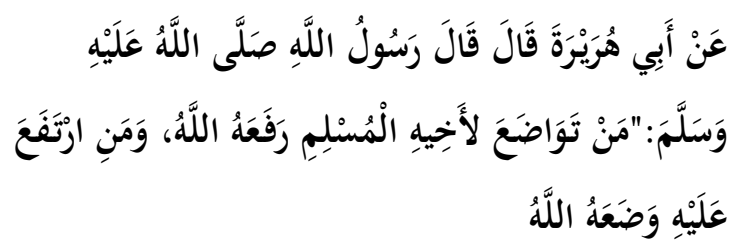

Dalam Kitab Majma' az-Zawaid wa Manba' al-Fawaid Syarh al-Mu'jam al-Ausath ath-Thabarani (VII/400), alHaitsami menyebutkan bahwa salah seorang periwayat dalam sanadnya bernama Abd al-'Azhim bin Habib adalah daif. Dengan demikian, hadis ini daif.

Hadis ke- 58.Dari Wail bin Hujr:

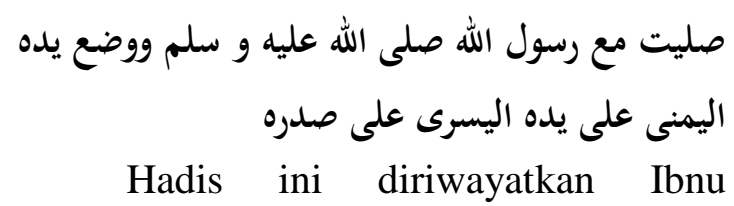

Khuzaimah bersumber dari Wail bin Hujr.
Menurut al-Albani sanad hadis ini daif, sebab salah seorang periwayat dalam sanadnya bernama Ibnu Ismail hapalannya buruk.

Hadis ke- 67.HR. Abu Daud dari Abu Hurairah:

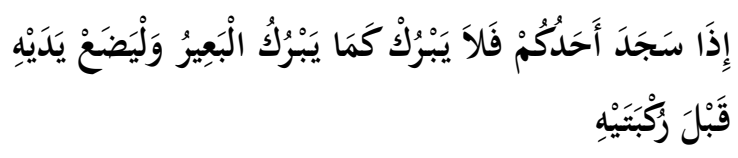

Hadis ini, selain diriwayatkan Abu

Daud dari Abu Hurairah, juga diriwayatkan Nasai, Ahmad dan Baihaqi semuanya bersumber dari Abu Hurairah.Menurut Ibn al-Qayyim, hadis ini termasuk hadis maqlub (hadis yang tertukar matannya). Kalimat: وَلْيَضَعْ يَدَيْهِ قَبْبَ

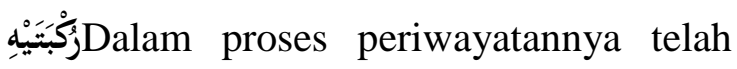
terjadi pertukaran. Kata “يَدَيْهْ" tertukar, seharusnya ditulis pada bagian akhir. Kata

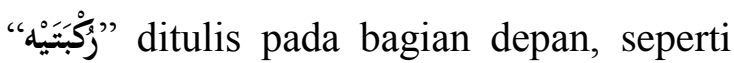
hadis yang diriwayatkan dari Anas ibn Malik dan Wail ibn Hujr.

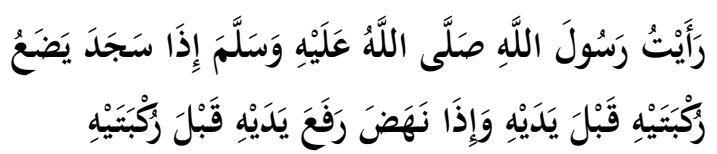

Saya melihat Rasulullah SAW.sujud meletakkan kedua lututnya sebelum kedua tangannya. Dan jika bangkit dari sujud, beliau mengangkat kedua tangannya sebelum kedua lututnya. (HR. Hakim dan Darimi). ${ }^{9}$

${ }^{9}$ Lihat Hakim, Ibid., Juz I h. 226; Sunan ad-Darimi Kitab as-Shalah Bab Awwal ma Yaqa'u 
Pendapat ini diikuti oleh Guru Besar Ilmu Hadis Universitas Damaskus Syiria, Prof. Dr. Nurdin `Itr dalam buknya Manhaj an-Naqd fi 'Ulum al-Hadits, buku yang banyak dipakai sebagai rujukan pada Program Pascasarjana Perguruan Tinggi Islam di dunia Islam. Hadis maqlub merupakan bagian dari hadis daif. Riwayat dari Wail bin Hujr dan Anas bin Malik adalah hadis fi'liyah yakni praktek Nabi SAW. secara langsung disaksikan ${ }^{10}$.

Ash-Shan'ani dalam kitabnya Subul as-Salam Syarh Bulugh al-Maram, mengatakan: "Bukhari menilai ada "cacat" dalam dalam sanad hadis ini. Kata Bukhari: "Salah seorang periwayat dalam sanadnya bernama Muhammad bin Abdullah bin Hasan tidak ada mutabi'-nya. Saya tidak tahu, apakah dia mendengar dari Abu Zanad atau tidak".Tirmidzi menilai hadis tersebut gharib (asing), kami tidak mengenal hadis dari Abu Zanad ini.Hadis gharib adalah hadis yang diriwayatkan dari seorang periwayat yang menyendiri.

Ibnu Khuzaimah meriwayatkan hadis dalam kitab Shahih Ibnu Khuzaimah dari Sa'ad bin Abi Waqqas, katanya:

min al-Insan 'ala al-Ardh Juz I h. 245 Hadis No. 1326. (Selain itu, hadis ini diriwayatkan juga Tirmidzi dalam Sunannya pada hadis no. 248 dan Abu Daud pada hadis no. 713 dalam Sunannya.

${ }^{10}$ Nûr ad-Dîn'Itr, Manhaj an-Naqd fî

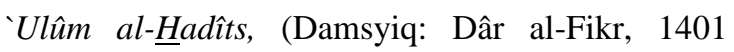
H/1981 M.).

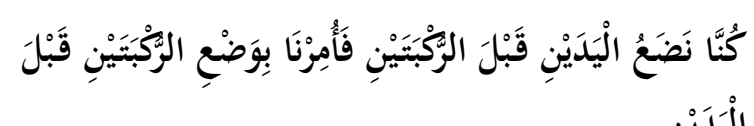

Kami (pada awalnya) meletakkan kedua tangan sebelum kedua lutut, lalu kami diperintahkan meletakkan meletakkan kedua lutut sebelum kedua tangan.

Dalam ilmu nasikh dan Mansukh, salah satu kalimat yang menunjukkan bahwa hadis itu mansukh (dibatalkan) adalah ketika dulunya dilakukan, lalu muncul perintah berikutnya untuk merubahnya.Maka yang menjadi pegangan adalah perintah yang terakhir.Sama halnya ketika awal-awal Islam, Umat Islam dilarang ziarah kubur, lalu setelah itu muncul kebijakan membolehkan bahkan menganjurkan ziarah kubur.Maka yang menjadi pedoman adalah kebijakan terakhir bolehnya ziarah kubur.Demikian juga, sebaliknya pada awalnya dibolehkan nikah mut'ah, tetapi setelah itu ada hadis berikutnya sebagai kebijakan larangan mut'ah.Maka yang menjadi pedoman adalah kebijakan terakhir, yaitu larangan nikah mut'ah.Dengan demikian, hadis ke67 di atas termasuk hadis maqlub sebagai bagian dari hadis daif, sebagaimana penilaian Ibnul Qayyim dan Nurdin 'Itr.

Hadis ke- 80.

Dari Sahl bin Mu'adz Ra., Rasulullah SAW. bersabda: "Barangsiapa hafal alQur'an dan menyempurnakan hafalannya serta mengamalkan isinya, nanti pada hari kiamat Allah akan memakaikan mahkota pada orang tuanya yang cahayanya lebih indah dari sinar matahari. (HR. Ahmad). 
Adapun teks hadis sebenarnya yang dimaksud adalah:

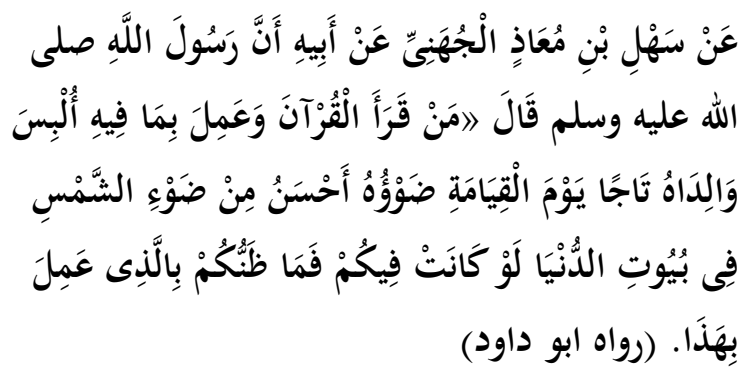

Terjemahannya yang benar adalah: "Dari Mu'adz al-Juhani, bahwa Rasulullah SAW. bersabda: "Barangsiapa membaca alQur'an lalu mengamalkan isinya, maka kedua orangtuanya akan dipakaikan mahkota pada hari kiamat. Sinarnya lebih bagus daripada sinar matahari di rumahrumah di dunia. ..... (HR. Abu Daud).

\section{Dalam kitab Majma' az-Zawaid wa} Mamba' al-Fawaid disebutkan bahwa hadis tersebut, selain diriwayatkan Abu Daud, juga Ahmad bin Hambal meriwayatkannya. Menurutnya, salah seorang periwayat dalam sanadnya bernama Zaban bin Faid adalah daif, maka hadis tersebut adalah daif. Hadis yang diriwayatkan Abu Daud juga daif menurut penilaian Syekh al-Albani.

Hadis yang Sangat Daifada dua:

Nabi saw pernah menyatakan tentang kelebihan yang dimiliki al-Qur'an: "Keutamaan kalamullah dibandingkan dengan kalam yang lain adalah seperti Allah dibandingkan dengan makhlukNya." (HR. Tirmidzi).

Adapun teks hadis dari terjemahan tersebut adalah hadis Qudsi, berupa firman Allah yang dibahasakan oleh Nabi
Muhammad SAW., yang bersumber dari Abu Said, yaitu:

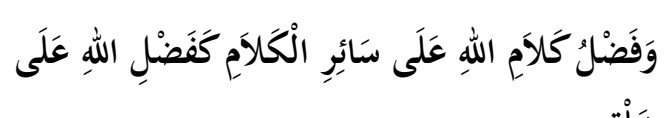

Ad-Darimi juga meriwayatkan hadis tersebut. Para ulama hadis menilainya sebagai daif, seperti Husain Salim Asad, menilai ada dua orang periwayat dalam sanadnya dinilai sangat daif, yaitu Muhammad bin al-Hasan alHamdani dan dan 'Athiyyah al-'Ufi. Bahkan al-Albani menilainya sangat daif.ضعيف جداً.

Hadis ke- 40,

$$
\begin{aligned}
& \text { عن علي بن أبي طالب رضي الله عنه, أن النبي صلى }
\end{aligned}
$$

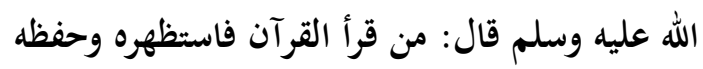

$$
\begin{aligned}
& \text { أدخله الله الجنة وشفَّعه فى عشرة من أهل بيته كلهم قد تر } \\
& \text { وجبت لهم النار (رواه احمد والترمذي) }
\end{aligned}
$$

Peneliti belum menemukan hadis ini sebagai riwayat Ahmad dan Tirmidzi.Hasil penelusuran ditemukan bahwa hadis ini diriwayatkan Baihaqi dalam kitab Sya'b al-Iman. Adapun riwayat Ahmad susunan redaksinya adalah:

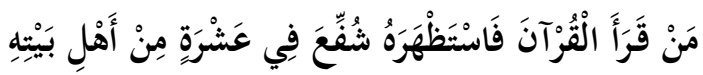

$$
\begin{aligned}
& \text { قَدْْ وَجَبَتْ لَهُمِ النَّارُ. }
\end{aligned}
$$

Syu'aib al-Arnauth dan al-Albani menilai bahwa hadis yang diriwayatkan Ahmad adalah sangat daif.Sedangkan riwayat Tirmidzi adalah: 


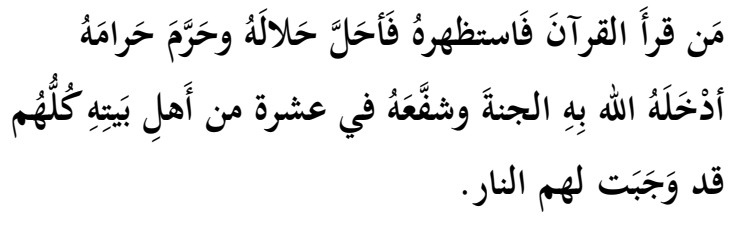

Hadis ini daif, disebabkan salah seorang periwayat dalam sanadnya bernama Hafsh bin Sulaiman adalah daif.

Hadis ke- 19

Barangsiapa mendengar seseorang yang berazan tetapi tidak suka mengabulkannya maka orang itu jelas tidak dikehendaki Allah menjadi orang yang baik dan tidak pula menghendaki adanya kebaikan untuk dirinya" (HR. Ibnu Abbas).

Terjemahan hadis ini hanya menyebutkan sumber riwayat dari kalangan sahabat, yaitu Ibnu Abbas, tanpa menyebutkan siapa yang meriwayatkannya. Hadis tersebut adalah riwayat Baihaqi dalam Sunannya (2/120) dan Abdurrazaq dalam al-Mushannaf (I/498), yaitu:

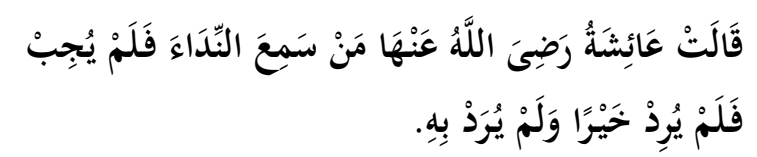

Riwayat ini bukanlah sabda Nabi SAW., melainkan ucapan Aisyah Radhiyallahu 'anha sendiri.Ucapan sahabat ini termasuk hadis mauquf. Terjemahan yang disebutkan di atas dinyatakan sebagai riwayat Ibnu Abbas.Dalam penelusuran peneliti tidak ditemukan sumbernya dari Ibnu Abbas, melainkan bersumber dari Aisyah sebagaimana diriwayatkan Baihaqi dan Abdurrazaq di atas. Adapun riwayat yang bersumber dari Ibnu Abbas adalah:
مَنْ سَمِعَ النّدَاءَ فَلَمْ يُجِبْ مِنْ غَيْرِ عُذْرِ فَلا صَلاةَ لَهُ. Barangsiapa yang mendengar adzan, namun ia tidak memenuhinya tanpa halangan, maka tidak ada shalatnya. (HR. Thabarani).

Riwayat ini juga mauquf seperti riwayat dari Aisyah di atas.

Hadis ke 26 adalah "Carilah ilmu dari buaian sampai liang lahat" (HR. Muslim).

Adapun teks Arabnya dari terjemahan di atas adalah: أُطْلُبُو الْعِلْمَ مِنَ الْمَهْدِ الَِى اللَّحَحِدِ

Apabila dilihat terjemahan tersebut disebutkan bahwa diriwayatkan Muslim, pasti disimpulkan bahwa hadis ini sahih.Padahal, hadis ini adalah palsu. Tidak pernah ditemukan dalam salah satu kitab hadis mana pun sehingga disimpulkan bahwa riwayat ini tidak ada sanad.As-Sidawi mengutip dari al-Ahâdîts al-Mardûdah (h. 12) karya Sa'id bin Shalih al-Ghamidi bahwa riwayat ini dinilai oleh Samahatusy Syaikh 'Abdul 'Aziz bin Bâz sebagai hadis yang tidak ada asalnya. ${ }^{11}$ Istilah seperti ini menunjukkan bahwa riwayat tersebut bukan hadis Nabi SAW. atau kalau disebut hadis berarti hadis palsu.

Adapun hadis yang ditulis terjemahannya "Sabda Rasulullah SAW: Bacalah al-Qur'an sesuai dengan cara dan suara orang-orang Arab. Dan jauhilah

\footnotetext{
${ }^{11}$ As-Sidawi, Koreksi Hadits-Hadits Dha 'if Populer ... hlm. 56.
} 
olehmu carabaca orang-orang fasiq dan berdosa besar. Maka sesungguhnya akan datang beberapa kaum setelhaku melagukan al-Qur'an seperti nyanyian dan rabbaniah (membaca tanpa tadabbur) dan nyanyian. Suara mereka tidak dapat melewati tenggorokan mereka (tidak dapat meresap ke dalam hati).Hati mereka dan orang-orang yang simpati kepada mereka telah terfitnah (keluar dari jalan yang lurus).

Ditemukan teks hadis dari terjemahan di atas adalah:

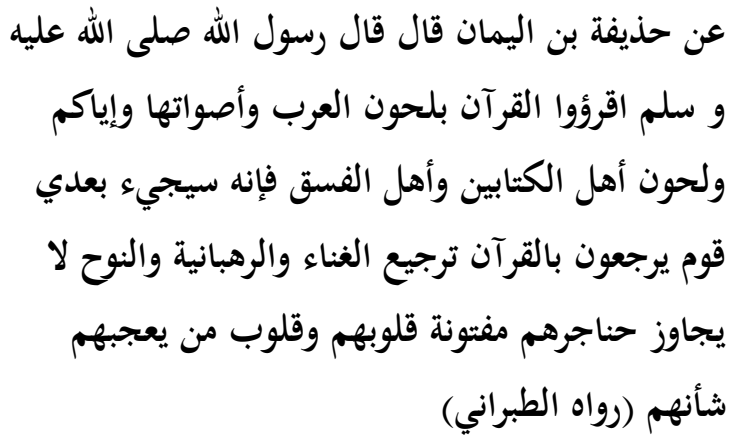

Hadis ini diriwayatkan Thabarani dalam al-Mu'jam al-Ausath bersumber dari Hudzaifah bin al-Yamani. Al-Baihaqi juga meriwayatkan dari Hudzaifah dalam Sya’b al-Iman. Hadis ini termasuk gharib, menyendiri dalam periwayatannya.Ada periwayatnya yang tidak disebutkan namanya.

\section{KESIMPULAN}

Ada dua macam cara penulisan hadis dalam skripsi mahasiswa: Pertama, hadis ditulis dalam teks Arab dan terjemahannya. Kedua, hanya terjemahan hadisnya yang ditulis. Dalam penulisan hadis teks Arabnya terdapat beberapa yang keliru. Bahkan ada yang teks hadisnya berbeda dengan terjemahannya. Ada beberapa hadis yang ditulis berulang-ulang dalam beberapa skripsi hingga 10 skripsi, hampir semuanya mengenai keutamaan membaca dan mengajarkan al-Qur'an. Hal ini terjadi, karena kebanyakan skripsi mengenai upaya peningkatan membaca alQur'an di suatu sekolah tertentu.

Adapun kualitas hadis-hadis dalam skripsi mahasiswa Jurusan Pendidikan Agama Islam Fakultas Tarbiyah dan Ilmu Keguruan IAIN Pontianak, adalah sebagai berikut: 86 hadis yang terdapat dalam 25 skripsi, ditemukan ada 66 hadis Sahih, 7 hadis Hasan, 8 hadis Daif, 2 hadis sangat daif, 1 hadis palsu, 1 sebagai ucapan sahabat atau mauquf, dan 1 hadis yang belum diketahui kualitasnya.

$$
\text { Pemahaman mahasiswa IAIN }
$$

Pontianak, khususnya Jurusan Pendidikan Agama Islam tahun akademik 2013/2014, dalam hal penulisan hadis dan kualitas hadis masih sangat kurang.Para pembimbing dan penguji skripsi tersebut termasuk lalai dalam hal penulisan hadis yang banyak keliru dan pemuatan hadishadis daif, sangat daif, bahkan ada hadis palsu yang disandarkan kepada imam Muslim sebagai periwayatnya. 


\section{DAFTAR PUSTAKA}

'Abd al-Muhdî ibn 'Abd al-Qâdir, (t.th). Thuruq Takhrîj Hadîts Rasûlillâh Shallâ Allâh `alaih wa Sallam, t. tp.: Dâr al-I'tishâm,

Ahmad ibn 'Alî ibn Hajar al-'Asqalânî, (1404 H/1984 M), Tahdzîb atTahdzîb, Beirût: Dâr al-Fikr, Cet. I.

Ahmad Lutfi Fathullah, (2016), 40 Hadis Mudah Dihafal Sanad dan Matan Riwayat Imam Muslim, Jakarta: alMughni Press, Cet. I.

Ahmad 'Umar Hâsyim, (t.th). Qawầid Ushûl al-Hadîts, Beirut: Dâr alFikr.

Ali Mustafa Yaqub, (1995), Kritik Hadis, Jakarta: Pustaka Firdaus.

Bustamin dan M. Isa H. A. Salam, (2004), Metodologi Kritik Hadis, Jakarta: Rajawali Press.

Jamâl ad-Dîn ibn `Ali ibn Muhammad ibn al-Jauzî, (1403 H/1983 M), Kitâb al-Maudhû'ât, Beirût: Dâr al-Fikr.

M. Abdurrahman dan Elan Sumarna, 2011, Metode Kritik Hadis, Bandung: Rosda, Cet. I.

M. Subana dan Sudrajat, (2005), DasarDasar Penelitian Ilmiah, Bandung: Pustaka Setia.

M. Syuhudi Ismail, (1992), Metodologi Penelitian Hadis Nabi, Jakarta: Bulan Bintang, Cet. I.

, 1988, Kaedah Kesahihan Sanad Hadis, Jakarta: Bulan Bintang, Cet. I.

Mahmûd `Ali Fayyad, (1419 H/1998), Manhaj al-Muhadditsin fi Dhabth as-Sunnah, diterjemahkan oleh A. Zarkasyi Chumaidy, "Metodolgi Penetapan Kesahihan Hadis", Bandung: Pustaka Setia.

Mahmûd Ath-Thahhân, (1412 H/1991 M), Ushûl at-Takhrîj wa Dirâsât al-
Asânîd, Riyâdh: Maktabah alMa’ârif, Cet. III.

Muhammad ibn Ahmad ibn 'Utsmân adzDzahabî, (1382 H/1963 M), Mîzân al-I tidâl fî Naqd ar-Rijâl, Halab: Dâr Ihyâ' al-Kutub, Cet. I.

Muhammad Mushthafâ A`zhamî, (1402 H/1982 M), Manhaj an-Naqd 'ind al-Muhadditsîn Nasy'atuhî wa Târikhuhû, Riyâdh: Syirkah athThibâ'ah al-`Arabiyah asSu'ûdiyah al-Mahdûdah, Cet. II.

Muhammad Thâhir al-Jawâbî, (t.th). Juhûd al-Muhadditsîn fî Naqd Matn alHadîts an-Nabawî̀ asy-Syarîf, Tunis: Muassasât "Abd al-Karîm ibn `Abdullâh.

Musfir 'Azhm Allâh ad-Damînî, (1404 H/1984 M), Maqâyis Naqd alMutûn as-Sunnah, Riyâdh: t.p., Cet. I.

Nûr ad-Dîn`Itr, (1401 H/1981 M.), Manhaj an-Naqd fi 'Ulûm alHadîts, Damsyiq: Dâr al-Fikr,

Suryadi dan Muhammad Alfatih Suryadilaga, (2009), Metodologi Penelitian Hadis, Yogyakarta: THPress.

Tim STAIN Pontianak, Profil Sekolah Tinggi Agama Islam Negeri Pontianak

Wajidi Sayadi, (2012), Aplikasi Ilmu Kritik Hadis dalam Menyeleksi Asbab anNuzul Studi atas Riwayat dalam Tafsir al-Maragi, Pontianak: STAIN Pontianak Press, Cet. I. 